\title{
Ground-Based Extraction on Salvage Logging in Two High Forests: A Productivity and Cost Analysis
}

\author{
Afraz Iranparast Bodaghi ${ }^{1}$, Mehrdad Nikooy ${ }^{2}$, Ramin Naghdi ${ }^{2}$, Rachele Venanzi ${ }^{3}$, \\ Francesco Latterini ${ }^{3}$, Farzam Tavankar ${ }^{4, *(D)}$ and Rodolfo Picchio ${ }^{3}$ (D) \\ 1 Department of Forestry, University Campus 2, University of Guilan, Rasht, 84475-41447, Iran; \\ iranparast_aukh@yahoo.com \\ 2 Department of Forestry, Faculty of Natural Resources, University of Guilan, Somehsara, 96196-43619, Iran; \\ nikooy@guilan.ac.ir (M.N.); rnaghdi@guilan.ac.ir (R.N.) \\ 3 Department of Agriculture and Forest Sciences (DAFNE), Tuscia University, Via S. Camillo de Lellis, \\ 01100 Viterbo, Italy; venanzi@unitus.it (R.V.); francesco.latterini@libero.it (F.L.); r.picchio@unitus.it (R.P.) \\ 4 Department of Forestry, Khalkhal Branch, Islamic Azad University, Khalkhal 56817-31367, Iran \\ * Correspondence: tavankar@aukh.ac.ir; Tel.: +98-045-3245-1220
}

Received: 27 September 2018; Accepted: 8 November 2018; Published: 22 November 2018

\begin{abstract}
Working time studies, work productivity, and cost assessments of forest logging are of interest to forest managers and planners. These aspects are particularly important in salvage logging, because of difficulties due to irregularly positioned fallen trees in forest areas, and due to particular aspects related to the absence of work planning. In this research, system productivity and the cost of salvage logging are analyzed for two mountain forests managed with close-to nature-silviculture: the Hyrcanian forest, using extraction by a skidder, and the Camaldoli forest, using extraction by tractors. The system productivity of salvage logging by skidders and tractors was calculated as 1.54 and $0.81 \mathrm{~m}^{3} \cdot \mathrm{h}^{-1}$, respectively. In contrast to common logging, system productivity was about $6-$ to 15 -fold lower in salvage logging. The effective cost consumptions for the skidder and tractor were calculated as $\$ 72.57$ and $\$ 118.62 \mathrm{USD} \cdot \mathrm{m}^{-3}$, respectively. For both yards, winching time increased due to increasing winching distance and winching load volume. The same result was determined for skidding time in relation to load volume and distance. The possible cost decreases for the skidder and tractor were calculated as $2.6 \%$ and $4.3 \%$, respectively. The results revealed that operational costs for extracting wind-fallen trees are higher than for traditional standing-trees extraction for both situations studied. In both cases, the harvesting costs were higher than the timber price by $10 \%$ to $30 \%$. Therefore, extraction of wind-fallen trees has no economic justification in these forests.
\end{abstract}

Keywords: salvage logging; extraction; time study; high forest; close-to-nature

\section{Introduction}

Globally, salvage logging is becoming more predominant for active forest-restoration purposes [1,2] and to recover economic value from timber in disturbed forests [3]. This study focused on two high forests, located, respectively, in Italy and Iran, up until the middle of the 19th century and a little further; the two forests under study were managed mainly for productive reasons with similar silvicultural treatments, in a shelterwood system. At present, both forests studied are managed with "close-to nature-silviculture" [4], restricting cuts to damaged and fallen trees. High biodiversity, extensive wildlife habitat, and the presence of more than 50 woody species indicate the ecological importance of these forests.

Even if there are no clear and official data for the two countries, in recent years, severe winds caused damage both in Iran and in Italy, but also in other temperate forests in the world. These new 
risks are due to climate change and warming and to a modified management system. In the future, these damages may increase, due to the shortening of the frozen soil period, which currently improves tree anchorage during the windiest season of the year from late autumn to early spring [5,6]. Windstorms are the dominant natural disturbance type in these typologies of mountain forests. In order to prevent biological diseases (fungi and insects) and to foster active forest-restoration, forest managers apply salvage logging in affected stands. Another goal for these particular logging activities could be to make income from the forest, even if without effective and active management. These interventions differ from the common planned logging activities, for the higher harvesting intensity [7], for the bigger number of younger trees harvested [8], and for the greater vulnerability of ecosystems as a consequence of the harmful event $[9,10]$.

Regarding the importance of salvage logging, there are different opinions among the real forest managers (forest engineering) and the ecologists. The main research results are not so clear, and frequently they are interpreted in a biased way. For example, some authors highlighted that these sporadic activities affect most taxa in different directions. Not surprisingly, the extensive removal of dead-wood resources by post-disturbance logging leads to a loss of species depending on such resources [11]. Forest harvesting after windstorm removes the storm-created pit-and-mound system, leading to homogenized structures, altered microsite diversity, and altered assemblages of vascular plants [12]. However, these non-positive aspects are hardly imputable to salvage logging and are mainly related to the forest-fallen cause.

Although fallen trees are ecologically important in forests ecosystems in terms of maintaining biodiversity; providing natural habitat; and supporting wildlife, run-off control, soil development, carbon sequestration, and preserving forest productivity, things can completely change when the fallen volumes are considerable and concentrated.

Considering the aspects discussed above, it is important to have a correct approach for proper, sustainable forestry regarding salvage logging. To preserve damaged timber from an infestation by fungi or beetles, forest managers rapidly operate on affected stands by post-disturbance salvage logging. Wind-fallen trees are difficult to harvest, and they do not always have high-value timber. The cost and productivity of forest harvesting machines are always of interest to forest managers and planners [13]. Having accurate information on the productivity of logging machines is an essential recruitment for the economic assessment of the forest production unit and the reduction of logging costs [14]. Based on the forest-machine operability in given site conditions, machine operating costs and productivity will be the two main factors in the appropriate selection of machines.

According to the steep slope condition, low road-density, and the structure and large diameter of trees, ground-based systems are the main extraction methods for logs, which are felled and processed by chainsaws. The productivity of logging machines depends on many factors such as machine type, tree size, logging intensity, the number of trees per hectare, terrain conditions, operator skills, silvicultural treatment, and distances between skid roads [15,16]. In the studied areas, the extraction systems were carried out by the skidder and the agricultural tractor, both equipped with winches.

For ground-based logging system applied by winching and skidding, there are many studies concerning typical and conventional silvicultural treatments [17-27]; otherwise, regarding salvage logging, few studies have been done [4,18,28,29], and there is a lack of knowledge about close-to-nature situations.

The main goals of this study were: (i) to develop a critical survey regarding time consumption for ground-based salvage logging in reduced-accessibility conditions, (ii) to develop time consumption models for the conditions studied, and (iii) to assess the production rates and the costs for these typologies of forest yards. These objectives were performed on salvage logging yards related to wind-fallen trees in two temperate forests, managed with "close-to nature-silviculture", considering their high biodiversity, extensive wildlife habitat, and the ecological importance of these forests. 


\section{Materials and Methods}

\subsection{Study Area}

\subsubsection{Hyrcanian Forest}

The Hyrcanian forests, with an area of 1.8 million ha, are located in the north of Iran, extending from the coast of the Caspian Sea to an altitude of $2800 \mathrm{~m}$ on the northern slopes of the Alborz mountain belt. High biodiversity, extensive wildlife habitat, and the presence of about 148 woody species highlight the ecological importance of these forests. The forests' structure is mixed broadleaf, and they are mainly managed as uneven-aged mountain forests. The standing volume is about $500 \mathrm{~m}^{3} \cdot \mathrm{ha}^{-1}$, and the most valuable tree species are beech (Fagus orientalis Lipsky), hornbeam (Carpinus betulus L.), alder (Alnus subcordata C.A.M.), and maple (Acer Spp.). The Hyrcanian forests have been managed by different silvicultural treatments: shelter wood-cutting from 1970 to 2000, selection cutting from 2000 to 2014, and restricted cutting to damaged and fallen trees from 2016 to the present. This research was carried out in compartments 214, 223, and 224 of the Nav district (latitude $37^{\circ} 38^{\prime} 34^{\prime \prime}$ to $37^{\circ} 42^{\prime} 21^{\prime \prime} \mathrm{N}$, longitude $48^{\circ} 48^{\prime} 44^{\prime \prime}$ to $48^{\circ} 52^{\prime} 30^{\prime \prime} \mathrm{E}$ ) in Hyrcanian forests, Guilan province, North Iran. The elevation of the compartments ranges from 1250 to $1400 \mathrm{~m}$ a.s.l. Average rainfall is $1050 \mathrm{~mm}_{\text {year }}{ }^{-1}$, with the heaviest rainfall in summer and autumn. The average daily temperature ranges from $-5{ }^{\circ} \mathrm{C}$ in December, January, and February, and up to $26{ }^{\circ} \mathrm{C}$ during summer (from June to September). These forests are natural uneven-aged, mixed broadleaved stands. In the studied area, Fagus orientalis and Carpinus betulus are the two main dominant tree species, and the companion species are Alnus subcordata, Acer platanoides L., Acer cappadocicum Gled., Ulmus glabra Hudsand, and Tilia rubra D.C. The soil type is forest brown (Alfisols), well-drained, and the texture varies between sandy clay loam and clay loam.

\subsubsection{Camaldoli forest}

The Camaldoli forest covers about $1100 \mathrm{ha}$, and it is located in the central part of Italy. Its elevation is between 1000 and $1200 \mathrm{~m}$ a.s.1., and the tree layer is characterized by pure, even-aged, and one-storeyed silver fir (Abies alba Mill.) stands planted at the end of the 19th century. The area is totally included in the Camaldoli State Biogenetic Nature Reserve, and within the National Park of Casentinesi Forests, Falterona Mountain, and Campigna. The standing volume reaches about $900 \mathrm{~m}^{3} \cdot \mathrm{ha}^{-1}$, and the most valuable tree species is silver fir. This research was carried out in parcel 149 (latitude $43^{\circ} 48^{\prime} 20^{\prime \prime}$ to $43^{\circ} 48^{\prime} 26^{\prime \prime} \mathrm{N}$, longitude $11^{\circ} 48^{\prime} 30^{\prime \prime}$ to $11^{\circ} 48^{\prime} 36^{\prime \prime} \mathrm{E}$ ). Average rainfall is $1150 \mathrm{~mm}$ year $^{-1}$, with the heaviest rainfall in spring and autumn. The average daily temperature ranges from $-10^{\circ} \mathrm{C}$ in January and February to $19{ }^{\circ} \mathrm{C}$ during summer (from June to September). These forests are created by artificial regeneration by plantation carried out at the end of the 1800s. In the studied area, silver fir (Abies alba Mill.) is the main dominant tree species, and the companion species are beech (Fagus sylvatica L.), plane-tree maple (Acer pseudoplatanus L.), Norway maple (Acer platanoides L.), lime tree (Tilia cordata Mill.), ash (Fraxinus excelsior L.), wych elm (Ulmus glabra Hudson), English yew (Taxus baccata L.), and holly (Ilex aquifolium L.). The soil type is forest brown (Alfisols), well-drained, and the texture is sandy clay.

\subsection{Data Collection and Analysis}

Tree density (stems $\cdot \mathrm{ha}^{-1}$ ) was calculated by counting all trees (diameter at breast height, $\mathrm{DBH} \geq$ $7.5 \mathrm{~cm}$ ) in circular plots of $1000 \mathrm{~m}^{2}$ centered on fallen trees. DBH was measured using a dendrometric caliper in $\mathrm{mm}$. Tree height, ground slope on the winching corridors, and skid trails were measured using a clinometer. The skid trail and winching corridor slopes (\%) were measured every $10 \mathrm{~m}$. Lengths of fallen tree, skid trail, and winching corridors were measured using strip meter in $\mathrm{cm}$. No correction was made for slope gradient, so these distances represent the actual paths covered by the extraction units [30]. The angle between the winching cable and the shortest route of logs to the skid trail was 
considered the winching angle and measured using a clinometer. Tree volume was obtained from a local volume table based on DBH and height of trees. The volume of winched logs was calculated by Huber's formula $\left(V=A_{m} \times L\right)$, in which $V$ is log volume $\left(\mathrm{m}^{3}\right), A_{m}$ is the middle point cross-sectional area of $\log \left(\mathrm{m}^{2}\right)$, and $\mathrm{L}$ is the length of $\log (\mathrm{m})$. Total extracted $\log$ volumes of studied forests in Italy and Iran were 756.5 and $463 \mathrm{~m}^{3}$, respectively.

Logging operations were carried out in summer of 2016. The study covered the regular working hours of the yard, and chainsaw and skidder/tractor operators. The working cycle for each operation consisted of certain elemental functions and factors. The working group included three people including a choker setter, chainsaw operator, and skidder/tractor operator. They had 10 to 20 years of work experience with their machines, and they were able to service and repair them.

The working cycles are reported for the two yards in Table 1. The extraction cycle started with unloaded travel and ended when the logs were piled at the landing. Based on field observations, the extraction cycle was separated into the following functional elements: travel unloaded of the skidder/tractor to the load (travel empty), cable releasing (pooling the hook), fallen-tree hooking, pre-winching of fallen tree, fallen-tree unhooking, delimbing, cross-cutting, log hooking, log winching, travel-loaded, log unhooking, and log pilling. As shown in Table 1, there was no tree-felling element; instead, three elements were added (fallen-tree hooking, pre-winching of fallen tree, and fallen-tree unhooking), which are not part of the traditional extraction cycle of standing trees [25,26,31]. The pre-winching was performed because the fallen trees were not on suitable ground conditions for delimbing and cross cutting. Continuous time was recorded to the nearest second with a stop watch, and the extraction operations were recorded by a digital video camera. The cycle times of the machines were divided into time elements (process steps) that were considered characteristic of this work. As suggested in Harstela [32] and Savelli et al. [33], working time was recorded for every phase. Based on recorded times and volume, the productivity per worker for the different operations was calculated as average gross productivity (Productive Hour System, PHS15), measured on the basis of time consumption, inclusive of all delays up to the maximum event duration of $15 \mathrm{~min}$; and average net productivity (PHS0), computed with the exclusion of delays [34].

For the yards, the machinery used are reported in Table 2. For extraction, in the Hyrcanian forests a skidder was used, which is a typical forestry machine, whereas in the Camaldoli forest a forestry-fitted tractor was used, which is a machine only sometimes used for forestry.

Table 1. Description of extraction cycle elements of salvage logging in the two yards.

\begin{tabular}{|c|c|}
\hline Time Element & Definition \\
\hline $\begin{array}{l}\text { Travel unloaded } \\
\quad \text { (TUL) }\end{array}$ & $\begin{array}{l}\text { Begins when the skidder/tractor leaves the roadside landing area, and ends when the } \\
\text { skidder/tractor arrives at the suitable position (nearest distance from the fallen tree) on the } \\
\text { skid trail }\end{array}$ \\
\hline $\begin{array}{l}\text { Cable releasing } \\
\quad(\mathrm{CR})\end{array}$ & $\begin{array}{l}\text { Begins when the skidder driver releases the cable, and ends when the choker setter is next } \\
\text { to the fallen tree }\end{array}$ \\
\hline $\begin{array}{l}\text { Fallen-tree hooking } \\
\qquad(\text { FTH) }\end{array}$ & $\begin{array}{l}\text { Begins when the choker setter wraps the cable around the lower part of the bole of fallen } \\
\text { tree, and ends when the skidder/tractor operator starts for pre-winching }\end{array}$ \\
\hline $\begin{array}{l}\text { Pre-winching of fallen tree } \\
\qquad \text { (PWFT) }\end{array}$ & $\begin{array}{l}\text { Begins when the driver starts to winch, and ends when the fallen tree arrives on suitable } \\
\text { condition }\end{array}$ \\
\hline $\begin{array}{l}\text { Fallen-tree unhooking } \\
\qquad(\text { FTUH) }\end{array}$ & $\begin{array}{l}\text { Begins when the choker setter opens the fallen tree, and ends when the fallen tree is } \\
\text { unhooked }\end{array}$ \\
\hline $\begin{array}{l}\text { Delimbing } \\
\text { (DL) }\end{array}$ & $\begin{array}{l}\text { Begins when the sawyer begins to cut the stump, branches, and top of fallen trees, and } \\
\text { ends when sawyer starts measuring the log lengths }\end{array}$ \\
\hline $\begin{array}{l}\text { Cross-cutting } \\
\quad(\mathrm{CC})\end{array}$ & $\begin{array}{l}\text { Begins when the sawyer measures the log length from the bottom of the tree bole and } \\
\text { marks the cross-cutting spots, and ends when the sawyer finishes the last of the } \\
\text { cross-cutting and logs are ready for hooking }\end{array}$ \\
\hline $\begin{array}{l}\text { Log hooking } \\
\text { (LH) }\end{array}$ & $\begin{array}{l}\text { Begins when the choker setter wraps the cable around the } \log (\mathrm{s}) \text {, and ends when the } \\
\text { skidder operator starts winching }\end{array}$ \\
\hline
\end{tabular}


Table 1. Cont.

\begin{tabular}{cl}
\hline Time Element & \multicolumn{1}{c}{ Definition } \\
\hline $\begin{array}{c}\text { Log winching } \\
\text { (LW) }\end{array}$ & Begins when the driver starts to winch, and ends when the logs arrive on skid trail \\
\hline $\begin{array}{c}\text { Travel-loaded } \\
\text { (TL) }\end{array}$ & $\begin{array}{l}\text { Begins when the skidder starts to move, and ends when the skidder arrives on roadside } \\
\text { landing }\end{array}$ \\
\hline $\begin{array}{c}\text { Log unhooking } \\
\text { (LU) }\end{array}$ & Begins when the choker setter opens the load, and ends when the log(s) is unhooked \\
\hline $\begin{array}{c}\text { Log pilling } \\
\text { (LP) }\end{array}$ & $\begin{array}{l}\text { Begins when the skidder/tractor driver starts to move and deck the logs on the landing, } \\
\text { and ends when load is piled up in final position and the skidder/tractor is preparing for } \\
\text { the next cycle }\end{array}$ \\
\hline
\end{tabular}

Table 2. Specification of the mechanization used in the two yards.

\begin{tabular}{ccccc}
\hline Forest & Hyrcanian Forest & Camaldoli Forest & \multicolumn{2}{c}{ Hyrcanian and Camaldoli Forests } \\
\hline \multicolumn{2}{c}{ Machine } & Machine \\
\hline Characteristics & Timberjack 450C & SAME 140 Virtus & Characteristics & Stihl ms880 \\
\hline Overall height/width $(\mathrm{mm})$ & $3023 / 3175$ & $2850 / 2609$ & Displacement $\left(\mathrm{cm}^{3}\right)$ & 121.6 \\
Power $(\mathrm{kW})$ & 120 & 95 & Power $(\mathrm{kW})$ & 6.4 \\
Total weight $(\mathrm{kg})$ & 10,270 & 6290 & Weight $(\mathrm{kg})$ & 10 \\
Front axle weight $(\mathrm{kg})$ & 5682 & 2516 & Bar length $(\mathrm{cm})$ & 90 \\
Rear axle weight $(\mathrm{kg})$ & 4588 & 3774 & Oil thank volume $(\mathrm{L})$ & 0.7 \\
Displacement $\left(\mathrm{cm}^{3}\right)$ & 6800 & 3849 & Thank volume $(\mathrm{L})$ & 1.30 \\
Number of cylinders & 6 & 4 & Number of cylinders & 1 \\
\hline
\end{tabular}

\subsection{Cost Analysis}

The hourly costs of the chainsaw, tractor, skidder, and equipment were calculated according to the Food and Agriculture Organization (FAO) method [35]. System costs were calculated by summarizing the machine and labor costs. The machines' costs were based on fixed costs (including the interest rate, depreciation, tax, and insurance) and variable costs (repair and maintenance, petrol, oil, lubricants, and wages of laborers). The total fixed cost was the sum of the interest, depreciation, and insurance. The costs of fuel, lubricants, service, maintenance, repair, chain, and tires were variable costs. Labor costs depended on the number of people and salary of each worker and the time hired to carry out the work. In both cases, almost all workers in the company were hired with a salary that was paid monthly. Personal costs included all costs, fringe benefits, and some bonuses and rewards [13,36]. Maintenance and repair costs were expressed as percentage of the machines' market-price.

The machine productivity was calculated based on time consumption (i.e., gross productivity inclusive of delays and net productivity excluding delays). Productive machine-hour (PMH) and Scheduled machine-hour (SMH) for the chainsaw were considered to be $240 \mathrm{~h}$ and $320 \mathrm{~h}$, respectively, and for the tractor and skidder, $900 \mathrm{~h}$ and $1200 \mathrm{~h}$, respectively, so that the utilization of the chainsaw and skidder were $75 \%$. Salvage values for the chainsaw and skidder were considered to be $10 \%$ [14]. The depreciation was calculated considering an economic life of 4 years for the chainsaw and 10 years for the tractor and skidder. Maintenance costs were calculated as a coefficient of depreciation. Overall, $15 \%$ of the fuel cost was considered to be an oil cost. The chain life was considered to be $240 \mathrm{~h}$. The cost items were calculated by Equations (1)-(14).

$$
\begin{gathered}
\mathrm{A}=[(\mathrm{P}-\mathrm{S})(\mathrm{N}+1)] / 2 \mathrm{~N}+\mathrm{S} \\
\mathrm{I}=\mathrm{A} \times \mathrm{I} \\
\mathrm{D}=(\mathrm{P}-\mathrm{S}) / \mathrm{N} \\
\mathrm{T}=(\mathrm{D}+\mathrm{I}) \times 10 \%
\end{gathered}
$$




$$
\begin{gathered}
\text { TFC }=\mathrm{I}+\mathrm{D}+\mathrm{T} \\
\mathrm{TFC}(\text { hour })=\mathrm{TFC} / \mathrm{SMH} \\
\mathrm{FLC}=\mathrm{FC}+\mathrm{OC}, \mathrm{OC} \text { is } 15 \% \text { of FC } \\
\mathrm{CC}=\mathrm{CP} / \mathrm{CL} \\
\mathrm{TC}=[(\mathrm{PT} \times \mathrm{NT})(1 \times \mathrm{i})] / \mathrm{N}(\text { hours }) \\
\text { TVC (hour })=\mathrm{MR}+\mathrm{FLC}+\mathrm{CC}+\mathrm{TC}
\end{gathered}
$$

in which:

$$
\begin{gathered}
\mathrm{MR}=[(\mathrm{P}-\mathrm{S}) /(\mathrm{N} \times \mathrm{PMH})] \times \mathrm{f} \\
\mathrm{TVC}=\mathrm{TVC}(\text { hour }) \times \mathrm{PMH} \\
\mathrm{LC}=\mathrm{N}_{\mathrm{W}} \times \mathrm{S}_{\mathrm{W}} \\
\mathrm{UC}=\mathrm{SC} / \mathrm{A}(\mathrm{E} \text { or } \mathrm{G}) \mathrm{Pr} \\
\mathrm{AEPr}=\mathrm{TV} / \mathrm{TT} \\
\mathrm{AGPr}=\mathrm{TV} / \mathrm{PT}
\end{gathered}
$$

in which $P$ is purchase price (USD), $A$ is annual investment (USD), $S$ is salvage value $(10 \%), N$ is economic life (year), $\mathrm{I}$ is interest (USD), $\mathrm{i}$ is interest rate (15\%), $\mathrm{D}$ is deprecation (USD), $\mathrm{T}$ is insurance (USD), TFC is total fixed cost (USD), PMH is productive-machine hour, MR is maintenance and repair cost $\left(\right.$ USD $\left.\cdot h^{-1}\right), f$ is the repair factor, FLC is fuel and oil cost $\left(U S D \cdot h^{-1}\right), F C$ is fuel cost $\left(U S D \cdot h^{-1}\right)$, OC is oil cost (USD $\left.\cdot h^{-1}\right), C C$ is chain cost $\left(U S D \cdot h^{-1}\right), C P$ is chain price (USD), CL is chain life (h), TC is tire cost (USD $\cdot h^{-1}$ ), PT is tire price (USD), NT is number of tires, $\mathrm{N}$ is $4000 \mathrm{~h}$, TVC is the hourly total variable cost $\left(\mathrm{USD} \cdot \mathrm{h}^{-1}\right), \mathrm{LC}$ is labor cost $\left(\mathrm{USD} \cdot \mathrm{h}^{-1}\right), \mathrm{N}_{\mathrm{W}}$ is number of workers, $\mathrm{S}_{\mathrm{W}}$ is salary of worker $\left(\mathrm{USD} \cdot \mathrm{h}^{-1}\right), \mathrm{UC}$ is unit cost $\left(\mathrm{USD} \cdot \mathrm{m}^{-3}\right), \mathrm{SC}$ is system cost $\left(\mathrm{USD} \cdot \mathrm{h}^{-1}\right), \mathrm{AEPr}$ is average effective productivity $\left(\mathrm{m}^{3} \cdot \mathrm{h}^{-1}\right)$, TV is total log volume $\left(\mathrm{m}^{3}\right)$, TT is total time $(\mathrm{h})$, AGPr is average gross productivity $\left(\mathrm{m}^{3} \cdot \mathrm{h}^{-1}\right)$, and PT is productivity time $(\mathrm{h})$.

\subsection{Statistical Analysis}

The first step of statistical analysis was checking for normality using the Kolmogorov-Smirnov test and homogeneity of variance using the Levene test. Different relationships were examined: between winching time, distance, and log volume for load; and between total extraction time and log volume for load. The relationships were analyzed by Pearson correlation test (data not showed) to check the proper implementation of regression analysis, performed by SPSS 19.0 software (New York, NY, USA) and STATISTICA 7.0 (Palo Alto, CA, USA).

\section{Results}

From the dendrometric analyses, we observed differences between the two forests (Table 3) that were affected by windstorm and subjected to salvage logging. Hyrcanian forests were typically uneven-aged with a medium standing volume, whereas Camaldoli forest was even-aged with a good standing volume. Considering the two forest types, windstorms behaved differently: in the Hyrcanian forests, mainly the largest trees fell and many younger trees remained standing, whereas in Camaldoli forest, almost all trees were affected by windstorms and fell.

The orographic and forest road-conditions analysis showed differences, with greater road density in the Hyrcanian forests and lower in the Camaldoli forests. The average slope of the forest area was much higher in the Camaldoli forest, even if, in terms of skid trail and winching corridor slopes, the two areas were similar (Table 4). 
Considering the dendrometric and orographic differences of the two forests, as well as the differences in terms of mechanization employed, Table 5 shows how, on average, Hyrcanian forests had a slightly higher average load extracted, albeit during the logging activities of a lower average length compared to Camaldoli forest.

Table 3. Average dendrometric stand characteristics before wind-storm for the two forests.

\begin{tabular}{ccc}
\hline \multirow{2}{*}{ Description } & Hyrcanian Forests & Camaldoli Forest \\
\cline { 2 - 3 } & \multicolumn{3}{c}{ Value } \\
\hline Tree density $\left(\mathrm{stem} \cdot \mathrm{ha}^{-1}\right)$ & 286.4 & 225.8 \\
Mean DBH $(\mathrm{cm})$ & 20.8 & 48.2 \\
Mean basal area $\left(\mathrm{m}^{2} \cdot \mathrm{ha}^{-1}\right)$ & 23.7 & 41.2 \\
Mean tree height $(\mathrm{m})$ & 19.7 & 33.2 \\
Standing volume $\left(\mathrm{m}^{3} \cdot \mathrm{ha}^{-1}\right)$ & 201.8 & 929.7 \\
Mean ground slope $(\%)$ & 25 & 39 \\
\hline
\end{tabular}

Table 4. Skid trail and corridors average features for the two forests.

\begin{tabular}{ccc}
\hline \multirow{2}{*}{ Description } & Hyrcanian Forests & Camaldoli Forest \\
\cline { 2 - 3 } & \multicolumn{2}{c}{ Value } \\
\hline Mean skid trail length $(\mathrm{m})$ & 308 & 195 \\
Mean skid trail slope $(\%)$ & 16.9 & 20.7 \\
Mean winching-corridor length (m) & $45.8 \pm 10.1$ & $49.8 \pm 9.5$ \\
Mean winching-corridor slope (\%) & 39.9 & 41.2 \\
Mean number of logs per turn & 1.86 & 1.25 \\
Mean log volume per turn $\left(\mathrm{m}^{3}\right)$ & $3.54 \pm 1.15$ & $2.54 \pm 1.01$ \\
Mean winching angle $\left(^{\circ}\right)$ & 13.2 & 21.5 \\
\hline
\end{tabular}

Table 5. Average dendrometric characteristics of extracted wood for the two forests.

\begin{tabular}{ccc}
\hline Description & Hyrcanian Forests & Camaldoli Forest \\
\hline Trees & \multicolumn{2}{c}{ Value } \\
\hline Total number (stem) & 106 & 192 \\
Mean DBH (cm) & 57.6 & 47.8 \\
Mean bole length $(\mathrm{m})$ & 13.2 & 12.5 \\
Mean volume $\left(\mathrm{m}^{3}\right)$ & 4.37 & 3.94 \\
\hline Log & \multicolumn{3}{|}{} \\
\hline Total number & 244 & 480 \\
Total volume $\left(\mathrm{m}^{3}\right)$ & 463.0 & 756.5 \\
Mean small diameter $(\mathrm{cm})$ & 35.8 & 28.6 \\
Mean large diameter $(\mathrm{cm})$ & 65.4 & 11.8 \\
Mean length $(\mathrm{m})$ & 7.3 & 1.58 \\
Mean volume $\left(\mathrm{m}^{3}\right)$ & 1.90 & \\
\hline
\end{tabular}

For the Hyrcanian forest, the average of total effective time was $134.3 \mathrm{~min}$ and the average total gross time per cycle was $138.1 \mathrm{~min}$ (Table 6). The most time-consuming activity was log winching $(30.1 \%)$, followed by cross-cutting $(15.1 \%)$, delimbing $(12.2 \%)$, and pre-winching $(11.4 \%)$. In the Camaldoli forest, the average of total effective time per cycle was $140.3 \mathrm{~min}$ and the average total gross time per cycle was $146.6 \mathrm{~min}$. The most time-consuming activity was the log winching $(29.7 \%)$, followed by cross-cutting $(14.5 \%)$, delimbing $(11.7 \%)$, and pre-winching of the fallen tree $(12.3 \%)$. 
Table 6. Description statistics of extraction cycle elements' time of salvage logging for the two forests.

\begin{tabular}{ccccc}
\hline \multirow{2}{*}{ Time element - (Mean \pm SD) } & \multicolumn{2}{c}{ Hyrcanian Forests } & \multicolumn{2}{c}{ Camaldoli Forest } \\
\cline { 2 - 5 } & Value (minutes) & \% of TGT & Value (minutes) & \% of TGT \\
\hline Travel unloaded (TUL) & $3.1 \pm 2.4$ & 2.2 & $2.4 \pm 1.1$ & 1.6 \\
Cable releasing (CR) & $5.6 \pm 0.6$ & 4.1 & $3.9 \pm 1.4$ & 2.7 \\
Fallen-tree hooking (FTH) & $5.8 \pm 1.7$ & 4.2 & $5.3 \pm 2.1$ & 3.6 \\
Pre-winching of fallen tree (PWFT) & $15.8 \pm 4.9$ & 11.4 & $18.1 \pm 2.7$ & 12.3 \\
Fallen-tree unhooking (FTUH) & $3.5 \pm 0.9$ & 2.5 & $3.3 \pm 1.0$ & 2.3 \\
Delimbing (DL) & $16.8 \pm 4.2$ & 12.2 & $17.1 \pm 3.1$ & 11.7 \\
Cross-cutting (CC) & $20.8 \pm 6.8$ & 15.1 & $21.3 \pm 4.4$ & 14.5 \\
Log hooking (LH) & $6.2 \pm 1.7$ & 4.5 & $5.5 \pm 1.1$ & 3.8 \\
Log winching (LW) & $41.6 \pm 10.5$ & 30.1 & $43.6 \pm 5.6$ & 29.7 \\
Travel-loaded (TL) & $8.3 \pm 3.0$ & 6.0 & $13.6 \pm 1.4$ & 9.3 \\
Log unhooking (LU) & $1.2 \pm 0.5$ & 0.9 & $1.1 \pm 0.2$ & 0.8 \\
Log pilling (LP) & $5.6 \pm 1.3$ & 4.1 & $5.1 \pm 1.9$ & 3.5 \\
Average delay-time per cycle (DT) & $3.8 \pm 0.9$ & 2.7 & $6.3 \pm 2.1$ & 4.3 \\
Total effective-time per cycle (TET) & $134.3 \pm 33.1$ & - & $140.3 \pm 27.6$ & - \\
Total gross-time per cycle (TGT) & $138.1 \pm 35.8$ & 100.0 & $146.6 \pm 31.2$ & 100.0 \\
\hline
\end{tabular}

The official average labor cost was considered based on the respective national markets and calculated for every operation considering the whole working team. The results are reported in Table 7 as hourly labor cost per specific team. For a first analysis, we compared the total hourly costs for the two yards. Considering a total hourly machine cost of $4.40 \mathrm{USD} \cdot \mathrm{h}^{-1}, 67.20 \mathrm{USD} \cdot \mathrm{h}^{-1}$, and $50.80 \mathrm{USD} \cdot \mathrm{h}^{-1}$ for the chainsaw, skidder, and tractor, respectively, the most expensive system appeared to be the one applied in the Hyrcanian forests. However, this was only marginally true, because the real yard cost is only related to work productivity.

Table 7. Summary cost assessment of mechanization used in the salvage logging activities studied.

\begin{tabular}{|c|c|c|c|}
\hline Cost Element of & $\begin{array}{c}\text { Value for Chainsaw of } \\
\text { Stihl ms880 }\end{array}$ & $\begin{array}{l}\text { Value for Skidder of } \\
\text { Timberjack 450C }\end{array}$ & $\begin{array}{l}\text { Value for tractor SAME } 140 \\
\text { Virtus with Forest Winch }\end{array}$ \\
\hline Purchase price (USD) & 1674.00 & $155,000.00$ & $137,000.00$ \\
\hline Salvage value (USD) & 167.40 & $15,500.00$ & $13,700.00$ \\
\hline Economic life (Year) & 4 & 10 & 10 \\
\hline Chain life (h) & 240 & - & - \\
\hline Tire life $(\mathrm{h})$ & - & 4800 & 4800 \\
\hline Tire price (USD) & - & 3700.00 & 1900.00 \\
\hline Fuel cost $\left(U S D \cdot h^{-1}\right)$ & 1.50 & 7.20 & 6.10 \\
\hline Repair factor (f) & 0.60 & 0.90 & 0.85 \\
\hline Scheduled machine hour (SMH) (h) & 320 & 1200 & 1200 \\
\hline Utilization (\%) & 75.0 & 75.0 & 75.0 \\
\hline Productive machine hour (PMH) (h) & 240 & 900 & 900 \\
\hline Depreciation (USD year $^{-1}$ ) & 376.70 & $13,950.00$ & $12,330.00$ \\
\hline Interest (USD·year ${ }^{-1}$ ) & 166.40 & $13,833.80$ & $12,227.30$ \\
\hline Tax and insurance (USD year $^{-1}$ ) & 54.30 & 2778.40 & 2445.70 \\
\hline Total fixed cost (USD. year ${ }^{-1}$ ) & 597.30 & $30,562.10$ & $27,013.00$ \\
\hline Total hourly fixed cost (USD $\left.\cdot h^{-1}\right)$ & 1.90 & 25.50 & 22.50 \\
\hline Total variable cost (USD. year ${ }^{-1}$ ) & 601.00 & $37,535.00$ & $25,470.00$ \\
\hline $\begin{array}{l}\text { Total hourly variable cost } \\
\text { (USD } \cdot \mathrm{h}^{-1} \text { ) }\end{array}$ & 2.50 & 41.70 & 28.30 \\
\hline Total hourly labor cost $\left(\mathrm{USD} \cdot \mathrm{h}^{-1}\right)$ & 19.92 & 20.54 & 20.54 \\
\hline System cost $\left(\mathrm{USD} \cdot \mathrm{h}^{-1}\right)$ & 24.32 & 87.44 & 71.34 \\
\hline
\end{tabular}

The main results for the two extraction systems studied are shown in Table 8. From this analysis, it can be seen that the Hyrcanian yard was the most productive and its delay times were lower (Hyrcanian forests 2.8\% and Camaldoli forest $4.3 \%$ ). This result was mainly due to the more efficient machinery used (skidder vs. tractor) and to the slightly gentler slopes in the Hyrcanian forests. 
Table 8. Summary of extracted logs differentiated between the two machines used.

\begin{tabular}{ccc}
\hline \multirow{2}{*}{ Item } & \multicolumn{2}{c}{ Value } \\
\cline { 2 - 3 } & Skidder Timberjack 450C & Tractor SAME 140 Virtus with Forest Winch \\
\hline Total number of cycles & 131 & 384 \\
Total extracted log volume $\left(\mathrm{m}^{3}\right)$ & 463.0 & 756.5 \\
Study duration $($ day) & 43 & 134 \\
Total gross time & 301.5 & 938.2 \\
Total delay time $(\mathrm{h})$ & 8.3 & 40.3 \\
Total productive time $(\mathrm{h})$ & 293.2 & 897.9 \\
Average effective productivity $\left(\mathrm{m}^{3} \cdot \mathrm{h}^{-1}\right)$ & 1.58 & 0.84 \\
Average gross productivity $\left(\mathrm{m}^{3} \cdot \mathrm{h}^{-1}\right)$ & 1.54 & 0.81 \\
\hline
\end{tabular}

Table 9 shows the final results of the two forests studied in terms of time and cost consumption related to a single felled tree and unitary timber volume $\left(\mathrm{m}^{3}\right)$. From these results, the Hyrcanian forests yard was the most profitable.

Table 9. Time and cost consumption for extraction of each fallen tree and unitary timber volume $\left(\mathrm{m}^{3}\right)$.

\begin{tabular}{ccccc}
\hline \multirow{2}{*}{ Item } & \multicolumn{2}{c}{ Fallen tree } & \multicolumn{2}{c}{ Timber $^{\left(\mathbf{m}^{\mathbf{3}}\right)}$} \\
\cline { 2 - 5 } & Hyrcanian Forests & Camaldoli Forest & Hyrcanian Forests & Camaldoli Forest \\
\hline Gross time-consumption (h) & 2.84 & 4.89 & 0.65 & 1.24 \\
Net time-consumption (h) & 2.77 & 4.68 & 0.63 & 1.19 \\
Effective cost-consumption (USD) & 309.13 & 467.37 & 72.57 & 118.62 \\
Possible percentage of cost decrease $\%$ & 2.6 & 4.3 & 2.6 & 4.3 \\
\hline
\end{tabular}

In this yard, winching time increased by increasing winching distance and load volume; these three variables were related, as found by the regression analysis (Table 10) and shown in Figure 1.

Table 10. Hyrcanian forests, non-linear regression analysis with double independent variable for winching time in relation to winching distance and load volume, $R=0.829, R^{2} \mathrm{Adj}=0.678, p<0.001$.

\begin{tabular}{cccc}
\hline Description & Beta & Value & $p$-Level \\
\hline Intercept & & 36.314 & $<0.001$ \\
Winching distance $(\mathrm{m})$ & -0.911 & -0.857 & $<0.05$ \\
Load volume $\left(\mathrm{m}^{3}\right)$ & 0.290 & 2.626 & $<0.05$ \\
Winching distance $^{2}(\mathrm{~m})$ & 1.499 & 0.016 & $<0.001$ \\
\hline
\end{tabular}




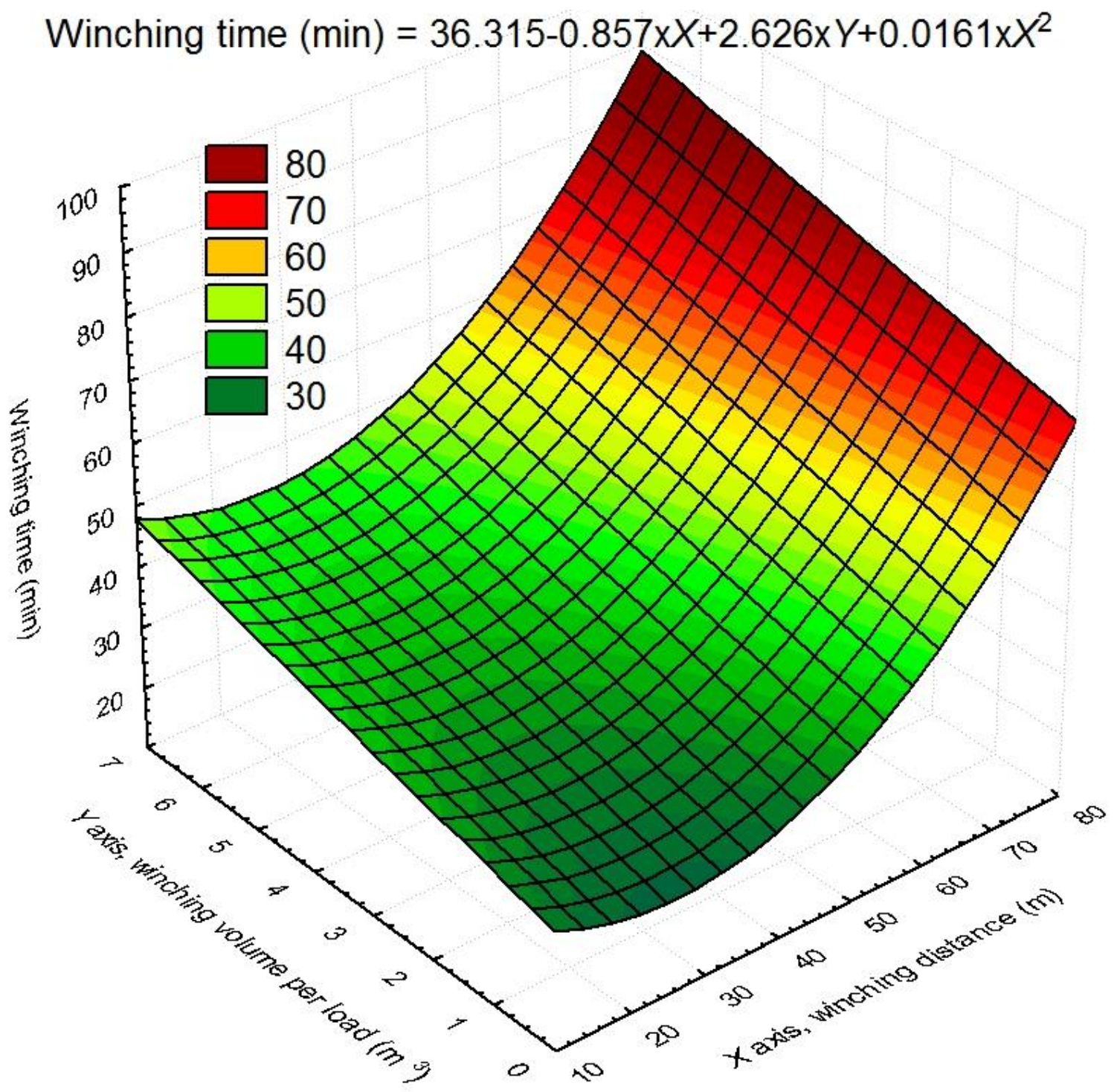

Figure 1. Tridimensional graphic of winching time in relation to distance and load volume, from the results of non-linear regression analysis (Table 10).

For the yard in the Hyrcanian forests, skidding time increased by increasing skidding distance and load volume; these three variables were related as found by the regression analysis (Table 11) and shown in Figure 2.

Table 11. Hyrcanian forests, and linear regression analysis with double independent variable for skidding time in relation to skidding distance and load volume, $R=0.833, R^{2} \mathrm{Adj}=0.684, p<0.001$.

\begin{tabular}{cccc}
\hline Description & Beta & Value & $p$-Level \\
\hline Intercept & & 0.420 & n.s. \\
Winching distance $(\mathrm{m})$ & 0.535 & 0.0202 & $<0.001$ \\
Load volume $\left(\mathrm{m}^{3}\right)$ & 0.301 & 0.697 & $<0.01$ \\
\hline
\end{tabular}




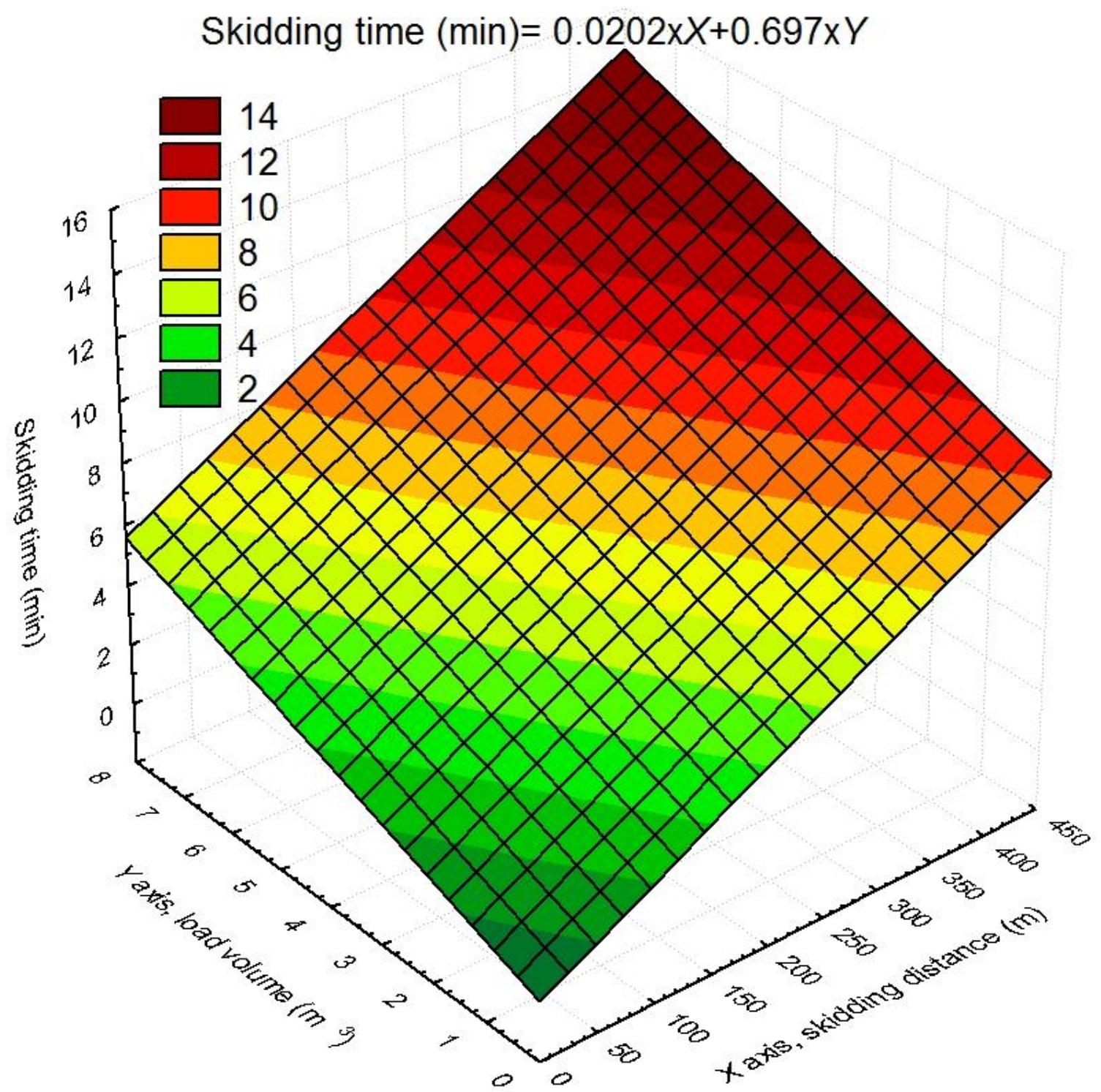

Figure 2. Tridimensional graphic of skidding time in relation to distance and load volume, from the results of linear regression analysis (Table 11).

For the yard in Camaldoli forest, winching time increased by increasing winching distance and winching load volume (Figure 3), and the same situation was found for the skidding time in relation to load volume (Figure 4), as result of the non-linear regression analysis with double variable (Tables 12 and 13).

Table 12. Camaldoli forest, non-linear regression analysis with double independent variable for winching time in relation to winching distance and load volume, $R=0.883, R^{2} \mathrm{Adj}=0.777, p<0.001$.

\begin{tabular}{|c|c|c|c|}
\hline Description & Beta & Value & $p$-Level \\
\hline Intercept & & -16.457 & $<0.05$ \\
\hline Winching distance $(\mathrm{m})$ & -0.425 & -0.268 & $<0.001$ \\
\hline Load volume $\left(\mathrm{m}^{3}\right)$ & -0.233 & -1.926 & n.s. \\
\hline $\log _{n}$ winching distance $(m)$ & 0.847 & 20.389 & $<0.001$ \\
\hline Load volume ${ }^{2}\left(\mathrm{~m}^{3}\right)$ & 0.806 & 1.068 & $<0.001$ \\
\hline
\end{tabular}




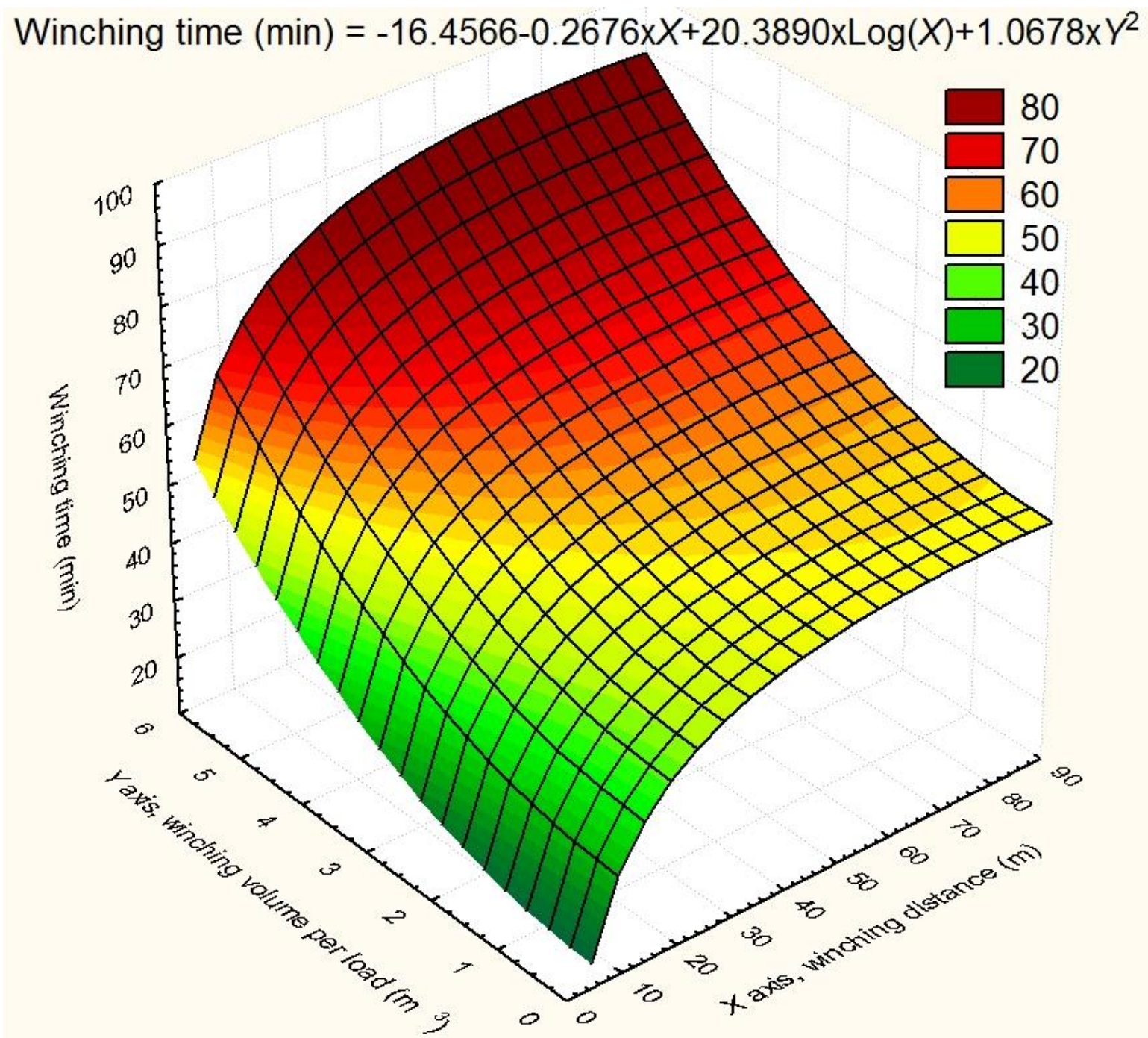

Figure 3. Tridimensional graphic of winching time in relation to distance and load volume, from the results of non-linear regression analysis (Table 12).

Table 13. Camaldoli forest, non-linear regression analysis with double independent variable for skidding time in relation to skidding distance and load volume, $R=0.847, R^{2} \mathrm{Adj}=0.711, p<0.001$.

\begin{tabular}{cccc}
\hline Description & Beta & Value & $p$-Level \\
\hline Intercept & & -0.661 & n.s. \\
Skidding distance $(\mathrm{m})$ & 1.424 & 0.089 & $<0.001$ \\
Load volume $\left(\mathrm{m}^{3}\right)$ & 0.032 & 0.205 & n.s. \\
Skidding distance $(\mathrm{m})$ & 0.885 & 0.00015 & $<0.001$ \\
Load volume ${ }^{2}\left(\mathrm{~m}^{3}\right)$ & 0.382 & 0.594 & $<0.05$ \\
\hline
\end{tabular}




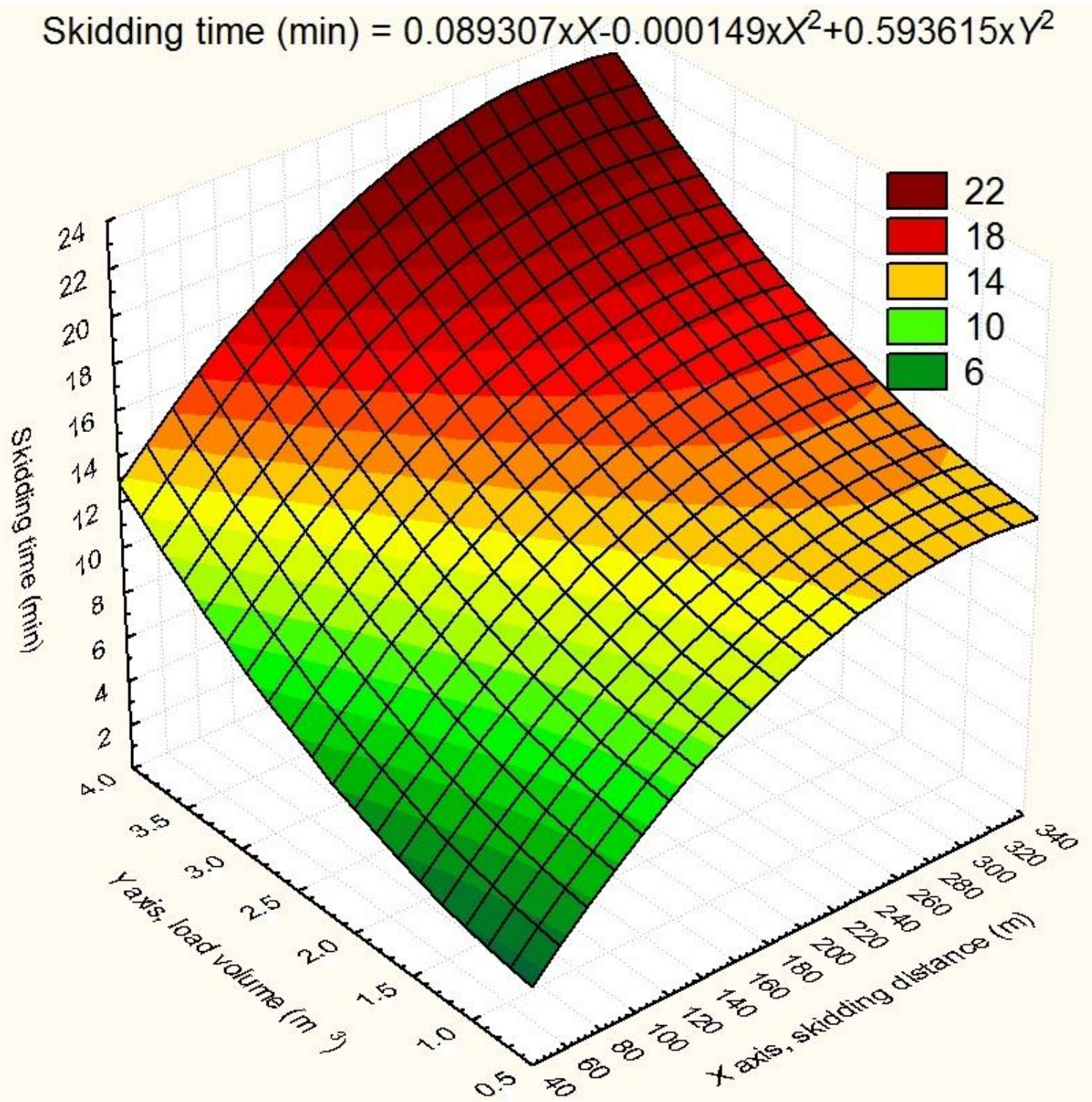

Figure 4. Tridimensional graphic of skidding time in relation to distance and load volume, from the results of non-linear regression analysis (Table 13).

\section{Discussion}

Logging cost analysis is an important step for the economic assessments that are crucial to evaluate business options [36] and forest restoration activities in forestry management. Costs evaluation of different harvesting alternatives is the basis for developing an efficient forest operation plan. This requires the estimation of production rates, equipment, and labor costs. Productivity analysis during salvage logging operations was completed by comparing two systems (skidder and tractor) in mountainous forests. In this research, the productivity of salvage logging in the Hyrcanian (skidder) and Camaldoli (tractor) forests was calculated, and the results showed that the average productivity of $1.54 \mathrm{~m}^{3} \cdot \mathrm{h}^{-1}$ for the skidder was about twice that of the tractor at $0.81 \mathrm{~m}^{3} \cdot \mathrm{h}^{-1}$. These results were compared to results of previous studies completed in similar conditions as the Hyrcanian forests $[13,14,25,31,37]$, and in some Italian conditions [38]. Compared to common logging, the system productivity is about 6- to 15-fold lower in salvage logging. In relation to the other research on salvage logging $[18,28]$ by ground-based system, mainly by skidder with winch, the gross average productivity was half for the skidder and a quarter for the tractor. The differences increase for the net 
average productivities; other studies found $6.53 \mathrm{~m}^{3} / \mathrm{h}$ in comparison to $1.58 \mathrm{~m}^{3} / \mathrm{h}$ (skidder used in our research) and $0.84 \mathrm{~m}^{3} / \mathrm{h}$ (tractor used in this research). These notable differences were mainly related to the different stand characteristics and to the different management systems applied.

The costs analysis of salvage logging produced values ranging from $\$ 72.6 \mathrm{USD} \cdot \mathrm{m}^{-3}$ to $\$ 118.6 \mathrm{USD} \cdot \mathrm{m}^{-3}$, costs about 10-40 times higher than in traditional logging. The reason for these lower productivities and higher costs in salvage logging is strictly related to the working conditions, since the inability to perform preliminary planning and issues related to the safety of the operators. Brzózko et al. [39] suggested that the cutting productivity in a wind-damaged harvesting site is 40\%-60\% lower than cutting under similar natural (i.e., normal) conditions. Dvo rák et al. [40] revealed that time consumption of cutting with broken stems increases by $7 \%$ compared to cutting normal stems, and the increase is 33\% when cutting of fallen trees in Norway spruce stands. Kärhä et al. [4] revealed that cutting productivity of windfalls is 19\%-33\% lower than productivity of undamaged stems. Furthermore, Kärhä et al. [4] underlined that cutting costs of windthrown stems with a volume of $0.3-1.5 \mathrm{~m}^{3}$ are $35 \%-64 \%$ higher than those of undamaged standing stems. Jaakkola [41] revealed that areas of windthrown stands are commonly smaller than those of normal stands, and therefore relocation costs are also higher. Distance and load volume were reported as influential factors on the productivity rate of a skidder in both winching and skidding operations [42]. In particular, it was found out that winching time increases with increasing winching distance. Relationship between winching time and winching distance for Hyrcanian forest is exponential (Figure 1), in contrast to Camaldoli forest, where this relationship is logarithmic (Figure 3). The differences in relationship models may be due to a different residual tree-density after windthrow, and a different pulling capacity of winches. Tree density in Hyrcanian forests was higher than Camaldoli forest. So, log winching through higher density stands takes more time than through lower density stands.

Relationship between skidding time and skidding distance was linear in the Hyrcanian forest (Figure 2) and logarithmic in the Camaldoli forest (Figure 4). The differences in relationship model may be due to difference in skid trail length and slope. Mean skid trail length in Hyrcanian forest was higher than Camaldoli forest, while mean skid trail slope in Hyrcanian forest was lower than Camaldoli forest.

Magagnotti et al. [43] improved downhill winching efficiency and reduced winching costs by using auxiliary winches on steep terrain in Italian hardwood forests. Winching is among the most common logging techniques in small-scale forestry, but it is inefficient and hard for the operators [43]. Winching is a labor-intensive task, because the winch cable must be pulled manually to the loading site for every single winching cycle [44]. As a result, winching imposes a heavy strain on the respiratory and circulatory systems of workers, and it is considered heavy physical work [45]. Therefore, winching productivity is relatively low $\left(<2 \mathrm{~m}^{3} \cdot \mathrm{h}^{-1} \cdot\right.$ worker $\left.^{-1}\right)$, which limits the level of compensation available for the operators and makes this job particularly unattractive [46,47]. Log winching was the most time-consuming activity in the work cycle, accounting for $41.6 \%$ of the total work time. The share of winching time was reported to be $47 \%$ of work cycle by Nikooy et al. [26].

Despite these negative aspects, in salvaging logging, the ground-based extraction system using winching and skidding phases seems to be the most practical. This is due to the limited ability to plan with respect to other systems, the greater flexibility, and the greater maneuvering capabilities of both the vehicle and the logs. Tavankar et al. [48] reported that the volume of fallen trees in selectively logged stands was twice as low as in protected stands in the Hyrcanian forests. Natural disturbances are an intrinsic part of forest ecosystem dynamics [49]. Forest disturbances are often coupled with large resource pulses of dead-wood, which additionally promote biodiversity [50]. Also, for salvage logging, another important aspect is related to the necessity of limiting damage to residual stand. Trees' health must remain a major objective in the "close-to-nature" and in the selective management of forests [51,52]. Logging workers must be convinced, through adequate training, that most damage to residual trees is unnecessary and avoidable [52]. 
The positive effects of natural disturbances to forest biota strongly depend on disturbance-created biological legacies. Controversially, salvage logging typically alters or removes these legacies [11]. To preserve biodiversity in post-storm salvage logging operations, a variety of biological legacies, such as root plates, small groups of regenerated trees, or sun-exposed dry branches, could be retained. Intermediate levels of natural disturbances can enhance structural heterogeneity of forest ecosystems, thus leading to higher biodiversity [53].

\section{Conclusions}

The management system for abiotic and biotic disturbances has changed in the last decades in the Iranian and Italian forests, which are expected to experience more frequent complex damage to their stands in the future. Therefore, we need to evaluate the possibility of completing salvage logging operations with adequate mechanization and proper methods. From the results of this study, we (1) developed a critical survey regarding the time consumption for ground-based salvage logging in reduced accessibility conditions, (2) developed time-consumption models for the conditions studied, and (3) assessed the production rates and costs for these types of forest yards. The importance of this study and the results are mainly related to the management systems, both of which could be classified as close-to-nature silviculture, considering their high biodiversity, extensive wildlife habitat, and the ecological importance of these forests.

The results revealed that operational costs of wind-fallen trees extraction are higher than traditional standing trees extraction for both situations studied. No tree-felling stage occurs; instead, pre-winching of fallen trees is an extra element in the extraction of wind-felled trees compared to standing-trees extraction. The winching distances of the wind-felled trees were more than the winching distances of standing trees. Notably, for these types of interventions, the choice of proper machinery (skidder vs. tractor) is more important than for common logging. For both situations, the harvesting costs were higher than timber prices by $10 \%$ to $30 \%$. Therefore, extraction of wind-fallen trees has no economic justification in these forests. With regards to dead wood ecologic importance, the extraction of wind-fallen trees should be managed to ensure an adequate balance between ecological, social, and economic functions. Deadwood has a wide range of ecological and conservation values, such as maintaining biodiversity and providing carbon sequestration in forest ecosystems. If the amount of wind-fallen trees is low, the wood should be left in forest stands due to the increasing logging costs and increasing amount of deadwood in the forest. If the amount of wind-fallen trees is considerable, salvage logging is necessary. In these cases, damage to the remaining trees and soil disturbance during salvage logging should be considered. Low-cost and more environmentally friendly logging systems must be used for the extraction of wind-fallen trees in these forests.

Author Contributions: Conceptualization, A.I.B., M.N., R.N., F.T., and R.P.; methodology, A.I.B., M.N., R.N., F.T., and R.P.; investigation, A.I.B., M.N., R.N., R.V., F.L., F.T., and R.P.; data curation, A.I.B., M.N., R.N., R.V., F.L., F.T., and R.P.; writing—original draft preparation, A.I.B., M.N., R.N., R.V., F.L., F.T., and R.P.; writing一review and editing, F.T. and R.P.

Funding: This research received no external funding.

Acknowledgments: The authors gratefully acknowledge MIUR (Italian Ministry for education, University and Research) for financial support (Law 232/2016, Italian University Departments of excellence)-UNITUS-DAFNE WP3.

Conflicts of Interest: The authors declare no conflict of interest.

\section{References}

1. Mercurio, R.; Contu, F.; Scarfò, F. New approaches concerning forest restoration in a protected area of central Italy: An introduction. Scand. J. For. Res. 2010, 25, 115-120. [CrossRef]

2. Frattaroli, A.R.; Pirone, G.; Di Cecco, V.; Console, C.; Contu, F.; Mercurio, R. Beech-wood restoration in the Gran Sasso and Monti della Laga National Park (central Apennines, Italy). Plant Sociol. 2017, 54, 11-18. [CrossRef] 
3. Manetti, M.C.; Cutini, A. Tree-ring growth of silver fir (Abies alba Mill.) in two stands under different silvicultural systems in central Italy. Dendrochronologia 2006, 23, 145-150. [CrossRef]

4. Kärhä, K.; Anttonen, T.; Poikela, A.; Palander, T.; Laurén, A.; Peltola, H.; Nuutinen, Y. Evaluation of salvage logging productivity and costs in windthrown Norway spruce-dominated forests. Forests 2018, 9, 280. [CrossRef]

5. Peltola, H.; Kellomäki, S.; Väisänen, H. Model Computations on the Impact of Climatic Change on the Windthrow Risk of Trees. Clim. Chang. 1999, 41, 17-36. [CrossRef]

6. Gregow, H.; Peltola, H.; Laapas, M.; Saku, S.; Venäläinen, A. Combined Occurrence of Wind, Snow Loading and Soil Frost with Implications for Risks to Forestry in Finland under the Current and Changing Climatic Conditions. Silva Fenn. 2011, 45, 35-54. [CrossRef]

7. Schmiegelow, F.K.; Stepnisky, D.P.; Stambaugh, C.A.; Koivula, M. Reconciling salvage logging of boreal forests with a natural-disturbance management model. Conserv. Biol. 2006, 20, 971-983. [CrossRef] [PubMed]

8. Radeloff, V.C.; Mladenoff, D.J.; Boyce, M.S. Effects of interacting disturbances on landscape patterns: Budworm defoliation and salvage logging. Ecol. Appl. 2000, 10, 233-247. [CrossRef]

9. McIver, J.D.; Starr, L. Environmental Effects of Post Fire Logging: Literature Review and Annotated Bibliography; U.S. Department of Agriculture, Forest Service, Pacific Northwest Research Station: Portland, OR, USA, 2000.

10. Beschta, R.L.; Rhodes, J.J.; Kauffman, J.B.; Gresswell, R.E.; Minshall, G.W.; Karr, J.R.; Perry, D.A.; Hauer, F.R.; Frissell, C.A. Postfire management on forested public lands of the western United States. Conserv. Biol. 2004, 18, 957-967. [CrossRef]

11. Thorn, S.; Claus Bässler, C.; Svoboda, M.; Müller, J. Effects of natural disturbances and salvage logging on biodiversity—Lessons from the Bohemian Forest. For. Ecol. Manag. 2017, 388, 113-119. [CrossRef]

12. Waldron, K.; Ruel, J.-C.; Gauthier, S.; De Grandpré, L.; Peterson, C.J. Effects of post-windthrow salvage logging on microsites, plant composition and regeneration. Appl. Veg. Sci. 2014, 17, 323-337. [CrossRef]

13. Mousavi, R.; Nikooy, M.; Uusitalo, U. Time consumption, productivity, and cost analysis of the motor manual tree felling and processing in the Hyrcanian Forest in Iran. J. For. Res. 2011, 22, 665-669. [CrossRef]

14. Naghdi, R. Investigation and Comparison of Two Harvesting Systems: Tree Length and Cut-to-Length Method in Order to Optimize Road Network Planning in Neka, Iran. Ph.D. Thesis, Tarbiat Modares University, Tehran, Iran, 2005. (In Persian)

15. Wang, J.; Long, C.; McNeel, J.; Baumgras, J. Productivity and cost of manual felling and cable skidding in central Appalachian hardwood forests. For. Prod. J. 2004, 54, 45-51.

16. Demir, M. Investigation of timber harvesting mechanization progress in Turkey. Afr. J. Biotechnol. 2010, 9, 1628-1634. [CrossRef]

17. Biller, C.J.; Baumgras, J.E. Analysis of rubber-tired skidder cycle times on steep-slope hardwood sites. Trans. Am. Soc. Agric. Eng. 1988, 31, 68-72. [CrossRef]

18. Borz, S.A.; Ignea, G.; Popa, B. Modelling and comparing timber winching performance in windthrow and uniform selective cuttings for two Romanian skidders. J. For. Res. 2014, 19, 473-482. [CrossRef]

19. Borz, S.A.; Ignea, G.; Popa, B.; Iordache, E.; Spârchez, G. Estimating time consumption and productivity of roundwood skidding in group shelterwood system-A case study in a broadleaved mixed stand located in reduced accessibility conditions. Croat. J. For. Eng. 2015, 36, 137-146.

20. Spinelli, R.; Magagnotti, N. Comparison of two harvesting systems for the production of forest biomass from the thinning of Picea abies plantations. Scand. J. For. Res. 2010, 25, 69-77. [CrossRef]

21. Zečić, Ž. Comparison of productivity of skidder Ecotrac $120 \mathrm{~V}$ at timber skidding in haily and mountains conditions. Annal. Experimentis Silvarum Culturae Provehendis SPEC 2006, 5, 557-571.

22. Pir Bavaghar, M.; Sobhani, H.; Feghhi, J.; Darvishsefat, A.A.; Marvi-Mohajer, M.R. Investigation on production rate and cost of Timberjack-450C in two skid direction in combined harvesting system. Iran. J. For. Poplar Res. 2007, 15, 374-385. (In Persian)

23. Naghdi, R.; Firouzan, A.H.; Nikooy, M.; Barari, K. Evaluation of Production and Cost of HSM-904 Skidder and TimberJack C-405 in Forests of Wood and Paper Industries of Mazandaran. J. For. Wood Prod. 2010, 63, 91-102. (In Persian)

24. Jourgholami, M.; Majnounian, B. Evaluating and comparison of two skidding methods using wheeled cable skidder (Case study: Kheyrud forest, Noshahr). Iran. J. For. 2011, 3, 189-200. (In Persian) 
25. Behjou, F.K.; Majnounian, B.; Namiranian, M.; Dvořák, J. Time study and skidding capacity of the wheeled skidder Timberjack 450C in Caspian forests. J. For. Sci. 2008, 54, 183-188. [CrossRef]

26. Nikooy, M.; Esmailnezhad, A.; Naghdi, R. Productivity and cost analysis of skidding with Timberjack 450C in forest plantations in Shafaroud watershed, Iran. J. For. Sci. 2013, 59, 261-266. [CrossRef]

27. Vusić, D.; Šušnjar, M.; Marchi, E.; Spina, R.; Zečić, T.; Picchio, R. Skidding operations in thinning and shelterwood cut of mixed stands-Work productivity, energy inputs and emissions. Ecol. Eng. 2013, 61, 216-223. [CrossRef]

28. Borz, S.A.; Dinulicǎ, F.; Bîrda, M.; Ignea, G.; Ciobanu, V.D.; Popa, B. Time consumption and productivity of skidding Silver fir (Abies alba Mill.) round wood in reduced accessibility conditions: A case study in windthrow salvage logging form Romanian Carpathians. Ann. For. Res. 2013, 56, 363-375. [CrossRef]

29. Magagnotti, N.; Picchi, G.; Spinelli, R. A versatile machine system for salvaging small-scale forest windthrow. Biosyst. Eng. 2013, 115, 381-388. [CrossRef]

30. Magagnotti, N.; Spinelli, R. Financial and energy cost of low-impact wood extraction in environmentally sensitive areas. Ecol. Eng. 2011, 37, 601-606. [CrossRef]

31. Jourgholami, M.; Majnounian, B. Productivity and cost of wheeled skidder in Hyrcanian forest. Int. J. Nat. Eng. Sci. 2008, 2, 99-103.

32. Harstela, P. Work Studies in Forestry. In Silva Carelica 18; University of Joensuu Faculty of Forestry: Joensuu, Finland, 1991; pp. 1-41.

33. Savelli, S.; Cavalli, R.; Baldini, S.; Picchio, R. Small scale mechanization of thinning in artificial coniferous plantation. Croat. J. For. Eng. 2010, 31, 11-21.

34. Maesano, M.; Picchio, R.; Lo Monaco, A.; Neri, F.; Lasserre, B.; Marchetti, M. Productivity and energy consumption in logging operation in a Cameroonian tropical forest. Ecol. Eng. 2013, 57, 149-153. [CrossRef]

35. FAO. Cost Control in Forest Harvesting and Road Construction; Forestry Paper; Food and Agriculture Organization of the United Nations: Rome, Italy, 1992; Volume 99, pp. 101-189.

36. Picchio, R.; Spina, R.; Maesano, M.; Carbone, F.; Lo Monaco, A.; Marchi, E. Stumpage value in the short wood system for the conversion into high forest of a oak coppice. For. Stud. China 2011, 13, 252-262. [CrossRef]

37. Lotfalian, M.; Moafi, M.; Sotoudeh Foumani, B.; Akbari, R.A. Time study and skidding capacity of the wheeled skidder Timberjack 450C. J. Soil Sci. Environ. Manag. 2011, 2, 120-124.

38. Corona, P.; Ascoli, D.; Barbati, A.; Bovio, G.; Colangelo, G.; Elia, M.; Garfi, V.; Iovino, F.; Lafortezza, R.; Leone, V.; et al. Integrated forest management to prevent wildfires under mediterranean environments. Ann. Silvic. Res. 2015, 39, 1-22. [CrossRef]

39. Brzózko, J.; Szereszewiec, B.; Szereszewiec, E. Productivity of machine timber harvesting at the wind-damaged site. Ann. Warsaw Univ. Life Sci. SGGW Agric. 2009, 54, 41-49.

40. Dvo rák, J.; Walczyk, J.; Natov, P.; Hošková, P. Structure of the operating time of the harvesters during casual logging. Sylwan 2015, 159, 300-306.

41. Jaakkola, S. Windthrown salvaging is not a good business in Finland). Koneyrittäjä 2012, 4, 14-15.

42. Kluender, R.; Lortz, D.; McCoy, W.; Stokes, B.; Klepac, J. Productivity of rubber-tired skidders in southern pine forests. For. Prod. J. 1997, 47, 53-58.

43. Magagnotti, N.; Aalmo, G.O.; Brown, M.; Spinelli, R. A new device for reducing winching cost and worker effort in steep terrain operations. Scand. J. For. Res. 2016, 31, 602-610. [CrossRef]

44. Carbaugh, E.; Hensle, A. Farm Tractor Harvesting Systems; College of Natural Resources, Virginia Polytechnic Institute and State University: Blacksburg, VA, USA, 2005; p. 7.

45. Ottaviani-Aalmo, G.; Baardsen, S. Environmental factors affecting technical efficiency in Norwegian steep terrain logging crews: A stochastic frontier analysis. J. For. Res. 2014, 20, 18-23. [CrossRef]

46. Magagnotti, N.; Spinelli, R. Replacing steel cable with synthetic rope to reduce operator workload in log winching operations. Small-Scale For. 2012, 11, 223-236. [CrossRef]

47. Picchio, R.; Maesano, M.; Savelli, S.; Marchi, E. Productivity and energy balance in conversion of a Quercus cerris L. coppice stand into high forest in central Italy. Croat. J. For. Eng. 2009, 30, 15-26.

48. Tavankar, F.; Nikooy, M.; Picchio, R.; Venanzi, R.; Lo Monaco, A. Long-term effects of single-tree selection cutting management on coarse woody debris in natural mixed beech stands in the Caspian forest (Iran). iForest 2017, 10, 652-658. [CrossRef]

49. Pickett, S.T.A.; White, P.S. The Ecology of Natural Disturbance and Patch Dynamics; Academic Press Inc.: Orlando, FL, USA, 1985. 
50. Drever, M.C.; Goheen, J.R.; Martin, K. Species-Energy theory, pulsed resources, and regulation of avian richness during a mountain pine beetle outbreak. Ecology 2009, 90, 1095-1105. [CrossRef] [PubMed]

51. Tavankar, F.; Bonyad, A.; Majnounian, B. Affective factors on residual tree damage during selection cutting and cable-skidder logging in the Caspian forests, Northern Iran. Ecol. Eng. 2015, 83, 505-512. [CrossRef]

52. Tavankar, F.; Picchio, R.; Nikooy, M.; Lo Monaco, A.; Venanzi, R.; Iranparast Bodaghi, A. Healing rate of logging wounds on broadleaf trees in hyrcanian forest with some technological implications. Drewno 2017, 60, 65-80. [CrossRef]

53. Connell, J.H. Diversity in Tropical Rain Forests and Coral Reefs. Science 1978, 199, 1302-1310. [CrossRef] [PubMed]

(C) 2018 by the authors. Licensee MDPI, Basel, Switzerland. This article is an open access article distributed under the terms and conditions of the Creative Commons Attribution (CC BY) license (http:// creativecommons.org/licenses/by/4.0/). 